\title{
Swiss soiled seed prompts tolerance question
}

On July 1, the Swiss government's tolerance standard for genetic purity of food comes into effect. Switzerland is the first country in Europe to set a limit for genetic contamination, but current controversy over genetically contaminated corn seeds highlights the urgent EU-wide need for such a standard for crops.

In May, it was discovered by the Swiss Department of Agriculture (Bundesamt für Landwirtschaft; Bern) and the district president of Baden-Württemberg (Tübingen, Germany) that PioneerHi-Bred's (Des Moines, IA) nongenetically modified corn seed varieties, Ulla and Benicia, actually contained novel genes from a variety of corn genetically modified to be resistant to the corn borer, Bacillus thuringiensis.

Contamination of the seeds, which were harvested in the United States, was "probably caused by stray pollen during the growing season," says Ulrich Schmidt, managing director of Pioneer in Buxtehude, Germany, which represents the grain manufacturer in Switzerland. It is likely that incorporation of pollen from GM varieties into Ulla and Benicia occurred this way because "Pioneer does not offer a commercial GM variety of Ulla or Benicia."

Before the contamination was discovered, Pioneer had sold enough Ulla and Benicia seeds to sow 400 hectares (roughly $0.5 \%$ of total corn cultivation in Switzerland), about 200 hectares of which had already been planted.

Estimates of the amount of genetic contamination of non-GM DNA by GM DNA vary between 0.1 and $0.5 \%$-respectably below the limit set in both countries for contamination resulting from physical mixing of varieties. Under German and Swiss seed market laws, this "technical" contamination with seed from weed and other varieties can be as high as $3 \%$ and $5 \%$, respectively.

But because there are no tolerance standards set for genetic purity, the contaminated Pioneer seeds are not approved for release into the environment, and planting therefore infringes the Swiss environment conservation law (Umweltschutzgesetz), as well as violating the German gene technology law (Gentechnikgesetz). As a result, the Swiss Department of Agriculture (Bundesamt für Landwirtschaft, Bern) has prohibited the import and trade of contaminated Ulla and Benicia and has ordered the destruction of any already sown.

However, Pioneer and the entire grain industry are not able to guarantee the genetic

Ingeborg Fürst is a freelance writer working in Munich. purity of their conventional non-GM varieties, says Schmidt. "Genetic inserts are in the nature of things," agrees Rainer Linneweber, spokesperson for Novartis Seed (Bad

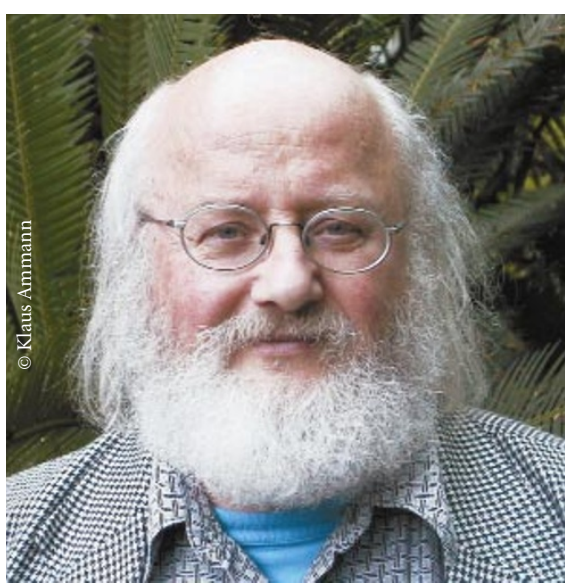

A witch hunt-like atmosphere reigns in Switzerland, says Commission for Biosafety member Klaus Ammann.

Salzuflen, Germany). "Despite our high-level quality management and our ISO certification, even a $100 \%$ [technical] purity for conventional seed is utopian," he adds. But although the Swiss government has now set a $1 \%$ tolerance standard for genetic contamination of food, such a standard for crops remains absent.

In the meantime, both Switzerland and Germany have analyzed the contaminated seed: The Swiss Department of Agriculture could detect by PCR the presence but not the amount of DNA sequences from GM corn varieties. But analysis ordered by the BadenWürttemberg district has called two specific GM varieties into question - one from Pioneer and one from another unnamed grain manufacturer, according to Grit Puchan, spokesperson for the BadenWürttemberg district.

"We still need to clarify whether or not these GM-corn seed varieties have been granted marketing approval in the EU and subsequently in Germany," says Puchan. If they have, the release of their contaminants would already be approved under the existing EU 90/220 directive. In this case, Pioneer must simply label the seeds accordingly to satisfy German authorities, says Edgar Muschketat, spokesperson for the Berlinbased Robert-Koch-Institüt, which approves the release of GMOs into the environment.

But this question is irrelevant, according to Hans-Georg Dederer, jurist at the Institute for Public Law at the University of Bonn, who says a loophole in the law means that geneti- cally contaminated seeds need no special approval under 90/220. "A crop genetically modified by stray pollen is not a product within the meaning of 90/220, because 'product' implies a willful preparation," he says.

Meanwhile, a "witch hunt-like atmosphere" reigns in Switzerland, says Klaus Ammann, director of the Botanic Garden at the University of Bern and member of the Commission for Biosafety (Kommission für biologische Sicherheit). But although some corn fields have been destroyed by fire or herbicides, many farmers (mainly in western Switzerland) refuse to destroy the corn until Pioneer and the Swiss government agree to compensate them. In addition, the Swiss farmers' association (Schweizerischer Bauernverband) is deciding whether to file a class action lawsuit against Pioneer (via the Swiss seed importer), and Pioneer is considering halting sales via the Swiss seed importer to farmers in Switzerland.

As Nature Biotechnology was going to press, the Swiss seed importer Eric Schweizer Samen AG agreed to pay farmers 700 Swiss Francs per hectare.

Ingeborg Fürst 